\title{
Dos Venus romanas de bronce halladas en la provincia de Toledo. Aproximación a una iconografía
}

\author{
Joaquín Aurrecoechea y Pilar Fernández Uriel *
}

\section{INTRODUCCIÓN}

El presente estudio está dedicado a un par de estatuillas de bronce pertenecientes a yacimientos toledanos tue son sendas representaciones de la diosa Venus. El interés de darlas a conocer es doble, ya que por una parte incrementan el nutrido grupo de la pequeña estatuaria broncínea $y$ por otra documentan esta industria en dos estaciones arqueológicas que son conocidas muy parcialmente.

Curiosamente, aunque Hispania ha proporcionado un buen número de ejemplares de este arte menor, nunca se ha intentado una sistematización completa de los mismos, salvo la recopilación que A. García y Bellido efectuó en la década de los cuarenta en su monumental obra sobre la escultura romana.

Desde entonces sólo han aparecido publicaciones que han dado a conocer piezas aisladas $y$, ocasionalmente, una visión de conjunto para alguna zona geográfica determinada, destacando los trabajos de F. Acuña Castroviejo para el área gallega (Acuña CASTRoviejo, F. 1972 y 1975).

Sería conveniente, por tanto, realizar un catálogo de estas manifestaciones artísticas como paso previo para la ejecución de una investigación a nivel peninsular. Valga el estudio de estas dos piezas que presentamos a continuación, hasta ahora inéditas, como incentivo y complemento a esta futura labor.

Ambas, como ya dijimos, pertenecen al ámbito toledano. Una fue hallada en Talavera de la Reina, la antigua Caesarobriga, ciudad que debió

* Departamento de Prehistoria e Historia Antigua. UNED. 
desempeñar un importante papel en el mundo romanizado de la Carpetania y de la que, sin embargo, conocemos solamente informaciones puntuales. Está actualmente depositada en los fondos del Museo de Santa Cruz.

La segunda estatuilla se encuentra adscrita a un yacimiento casi desconocido en el término de Ocaña, de cuyos materiales nos informamos gracias a una colección privada madrileña.

\section{Venus. Su culto y significación religiosa}

Venus-Afrodita es una divinidad femenina cuya categoría pertenece al rango de los 12 grandes dioses del panteón clásico.

Su personalidad y atribuciones divinas son sumamente complejas. Incluso pudiera ser considerada como una de las divinidades más versátiles, capaz de asimilar elementos exteriores mediterráneos, orientales, o helénicos .

Ello pudiera deberse a los antiquisimos origenes de la diosa, muy posiblemente derivados de una primitiva deidad mediterránea de la fecundidad o la vida vegetativa.

Esta complejidad aparece ya reflejada en el mito de su nacimiento: Mientras Homero la considera hija de Zeus y Dioné (lliada V, 312, 370 y $X X, 107$ ). [La versión de homero invita a confusión entre Afrodita y Hebe, hija de Zeus y de Hera], Hesiodo cuenta en su Teogonía el nacimiento de la diosa, saliendo de la espuma del mar, fruto del miembro viril de Urano, mutilado por Cronos: Venus Anadiomene. (Teogonia 188 y ss.). Esta versión de Hesiodo recibiría, tal vez, influencias de los mitos orientales de Citera y Chipre ${ }^{2}$.

Concretándonos a la Venus romana, autores como Cincio y Varrón señalan que Venus no figura en los testimonios históricos romanos más antiguos como los cantos salios o los documentos de la época de los

Sobre Venus ver Wissowa, R. E., “Aphrodite», págs. 2725-2729; DaRemberG-SaGLio, "Vénus", págs. 721-736; SCHILLING, R., "Les origines de la Vénus romaine", Latomus, n. ${ }^{\circ 17}, 1958$, págs. 175-190; idem, La réligion romaine de Vénus. Depuis les origines jusqu'au temps d'Auguste, 2. ${ }^{a}$ ed. París 1984; PICARD, CH., "Le couronnement de Vénus", MEFR, n. LVIII, 1941 1946, págs. 43-108; LASSUS, J., "Vénus marine”, CMGR, 1965, págs. 175-190.

${ }_{2}$ Esta variedad de los escritores griegos arcaicos se refleja en las versiones que nos han dejado los escritores latinos posteriores. Naevio cita a Venus como hija de Júpiter, mientras que Ennio, citado por Varrón aluden a la diosa como “Hija del mars: (De I.L., VIl; 51, EnNius, ANN., I, 52. También MACroBIO, S., VI, 2. 31). 

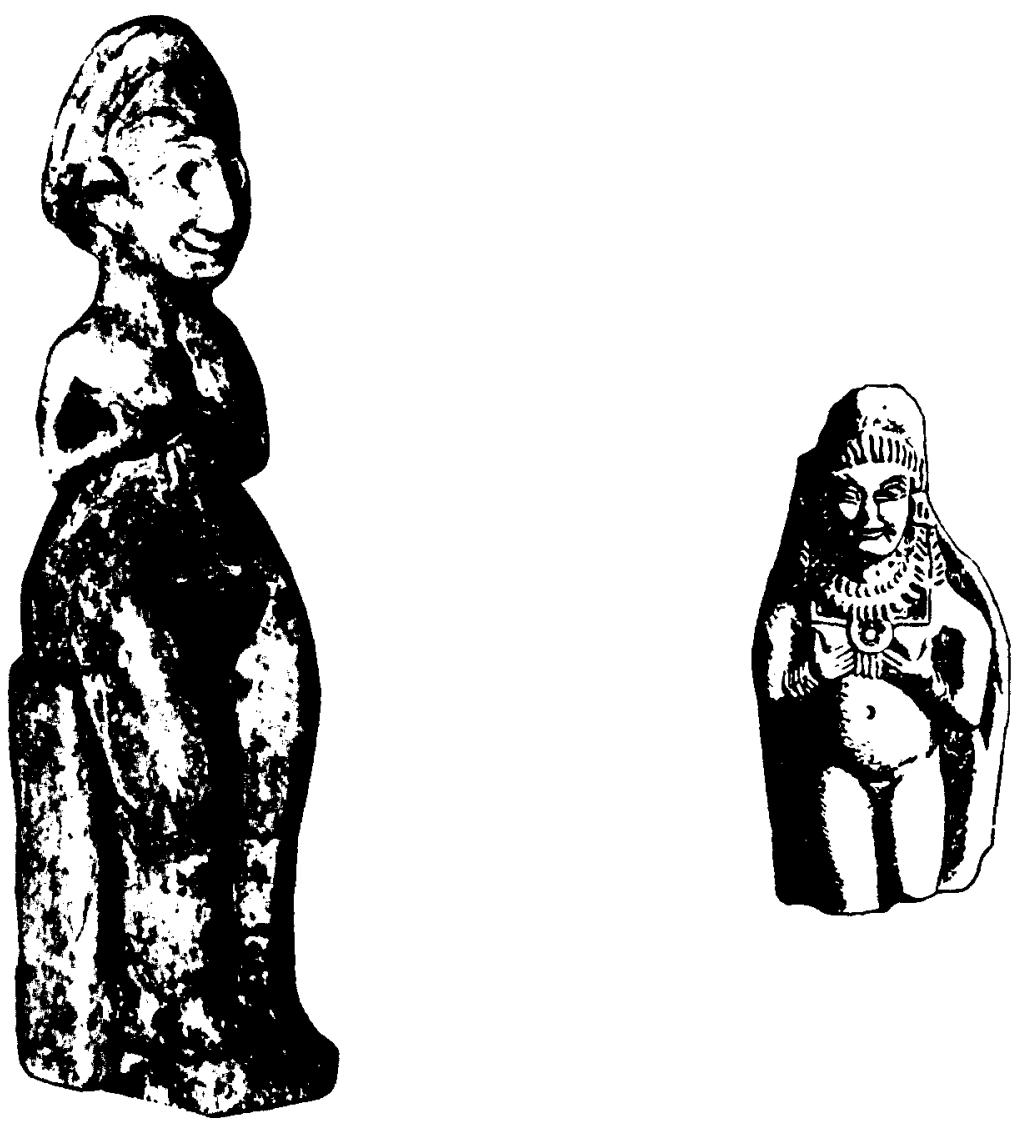

Fig. 1. Los origenes de Venus-Afrodita Pandémos pueden considerarse remotisimos, teniendo unos claros antecedentes en las divinidades del Próximo Oriente. Ejemplo de ello puede valer la estatuilla en marfil procedente de Siria, del II milenio a. C., que representa la diosa Ishtar (A). A su derecha (B), la representación de Afrodita Chipriota, fechada en torno al siglo $V$ a. C.

reyes. Sin embargo el culto de Venus en el Lacio debió tener unos remotos orígenes con un carácter netamente latino, como diosa de la vegetación, de los bosques y los jardines. Debido a ello esta diosa se identificaba con las divinidades primitivas: Murcia, Cloacina y Libitina, diosas que por otra parte cuentan con connotaciones funerarias. Precisamente estos mismos caracteres de la diosa facilitaron la asimilación de diversas influencias exteriores (oriental, etrusca y griega), que abordaron a la diosa más a 
que a ninguna otra divinidad femenina, logrando que Venus se manifestara en múltiples y variadas facetas ${ }^{3}$.

La confirmación de Venus en la religiosidad romana es plena ya en los siglos vi y $\vee$ a.C., afirmando sus caracteres latinos e identificándose con Roma desde los más remotos orígenes de su mítica fundación, asociada a Lavinium y a la leyenda de Eneas, como madre del héroe troyano y jugando un papel decisivo en la afirmación de la identidad latina, papel que nunca perdería, quedando unida a los principales momentos de la Historia romana en los que de una forma u otra aparece asociada. Quizá se deba a ello el que la diosa se manifieste marcada por las diversas vicisitudes que corre la ideología romana. Ello debió repercutir poderosamente en la evolución de la rica y diversa personalidad de Venus.

En Venus se conjugan la Granditas y la Gravitas romana manifestadas en Venus Victrix y Venus Genetrix. Pero también mantiene la dicotomía de frivolidad y misticismo de la Afrodita griega e incluso de las diosas orientales ${ }^{4}$.

Es decir, aunque Venus romana jamás dejó de «sentirse latina", absorbió el sincretismo religioso de otras divinidades femeninas secundarias $e$ incluso de carácter oriental aunque ya matizadas y envueltas de helenismo ${ }^{5}$.

Así, Venus, de una forma $u$ otra recibe todos las atribuciones y privilegios recogidos por Afrodita y su sincretismo religioso enriquece la personalidad de esta diosa que se revela en diversas manifestaciones:

- Diosa protectora de la Gens lulia y del pueblo romano. Su culto adquiere rango nacional y de Estado. (Venus Victrix y Venus Genetrix).

3 «Murcia, la tierra nutricia, dulce a los vivos, dulce a los muertos". BouCHE-LeCleaco, Man des inst. Rom., págs. 482 y ss.; Varron, De Len. Lat., V, 1954; Plinio, Nat. Hist., XV, 121; Plutarco, Quaest. Rom., 20; Serv., Ad Aen., VIII, 636; P.W. R.E., pág. 195.

4 La Afrodita griega ya era contemplada como divinidad armada por los griegos (Afrodita Akraia o defensora de las acrópolis). Su carácter guerrero aparece en Chipre y Citerea (PAUSANIAS, III, 23, 1), Corinto (PAUSAN IAS, II, 4, 7; Estrabon, VIII, 379) y en el Peloponeso, principalmente en Esparta y Argos <Afrodita Akria> (PAUSANIAS, III, 17, 5). Igualmente como diosa de la fecundidad, el matrimonio y la familia. El carácter maternal de la diosa se prolongaba incluso al nacimiento y educación de los hijos. Su naturaleza de "Curotrophos" era particularmente considerada ya en Atenas (Athen, $X, 58$ y XIII, 61) y su papel de diosa tutelar de la familia se afirma en la personalidad romana de Venus Genetrix.

5 R. Schilling subraya el fuerte componente etrusco en la identidad itálica y latina de Venus e identifica en ciertas atribuciones de la diosa aspectos del culto de las divinidades femeninas etruscas Frutis y de Turan, "la soberana". Sin embargo, este autor señala que la religiosidad etrusca recibió una notable influencia del mundo griego transfiriéndose ambas en la cultura e ideología romana sin solución de continuidad. SHILLING, Robert, La religion romaine de Vénus. Depuis les origines jusqu'au temps d'Auguste. Paris 1954, pág. 158. 
- Diosa de la belleza, del amor y del placer. Interpretada como divinidad orgiástica, de placer carnal, pero también de fertilidad en su carácter primitivo de Pandémos, relacionada con la mitología oriental, fenicia y chipriota (Recordemos que el nacimiento de Afrodita se situaba tradicionalmente en la costa chipriota) ${ }^{6}$.

- Diosa marina. Según la versión de Hesiodo, Afrodita surge de la espuma del mar como fruto del elemento líquido y reina sobre el mismo. Es Afrodita-Venus Anadiomene, la amante de Poseidón. La concha marina es su símbolo.

- Diosa etónica. Si es soberana del elemento líquido, también es de fecundidad terrestre como diosa de vegetación. A Venus le fue dedicado el mes de abril, cuando emergen las fuerzas vegetativas. Así escribe Horacio: Mensem Veneris marinae... aprilem (HoRacio, C. IV, II, 5) ${ }^{7}$.

Todas estas concepciones de la diosa confieren a la misma un notable poder sobre los principios y las fuentes de la vida y por lo tanto, de la muerte. Ello le otorga un carácter esotérico y funerario, no como divinidad propiamente de la muerte, sino como fuente renovadora de la vida y por to tanto, de inmortalidad ${ }^{8}$.

- Ya Platon en «El Banquete», trata de la dicotomía en esta personalidad de Afrodita: Urania y celeste que indicaría el amor puro, como nacida sin intervención de mujer y como hija de Zeus y Dioné representa el amor común y el placer (PLATON, El Banquete, 180-D, 81). Afrodita Pandémos significa el amor en su expresión más primitiva y tal vez más vulgar. La diosa muestra en su función de divinidad del placer, patrona de hetairas y meretrices. POMERoY, S. B., Diosas, rameras, esposas y esclavas. Madrid 1987, pág. 20.

$>$ Varrón ya indica que el mes de abril fue consagrado a Venus: «Secundus ut Fulvius scribit et lunius a Venere quod nusquam inveni, magis Puto dictum quod ver omnia aperit Aprilem", VI, 33. También MACroBıo, S., I, 12, págs. 112-113. Aprilis pudiera derivar del término griego Aphron = espuma.

- Las manifestaciones esotéricas y funerarias del culto de Venus-Afrodita son diversas: La figura de la diosa como Anadiomene, o la alusión a su símbolo, la concha marina son relativamente frecuentes en representaciones fúnebres (pinturas, relieves, inscripciones...). Cf. GriMAL, P., "Vénus et l'inmortalité", Hommage à Walter Deonna. Paris 1960, págs. 258 y SS.; PICARD, G. CH., "La Vénus funeraire des romains", Melanges d'Archéologie et d'Histoire de l'Ecole Franảise de Rome (MEFR), LVI-LVII, 1939-1940, págs. 131-135; Gross, P., Aurea Templa. Recherches sur l'Architecture religieuse de Rome à l'époque d'Auguste. Roma 1976, págs. 147-153. Según P. Gross, el papel funerario de Venus se afirma a partir del siglo ॥ d.C.; losı, E., "Gli scavi nelle sacre Grotte Vaticane", II Vaticano nel 1944. Roma 1945, págs. 6 y ss.; CALZA, G., La necropoli del porto di Roma nell'sola sacra. Roma 1940, págs. 119 y 174. Además del himno órfico alude a la naturaleza esotérica de la diosa a la que alude como "soberana de la vida" (Thea Basilea), cuyo culto mistérico se relaciona con Dióniso. Fruto de esta unión es Príapo, personaje itifálico, dios de la fecundidad, incluido en el cortejo dionisíaco y en los ritos de fertilidad (Pausanias, IX, 31, 2; OVIDio, Fas., I, 391; VIRGILIO, Georg., II, 84 y IV, 111; Diodoro, IV, 6. Ver Herter, H., De Priapo. Giessen 1932. Schilling, R., op. cit., págs. 220 y 221). 
Venus fue reconocida en Roma con tales connotaciones misticas y esotéricas, siendo representada con toda su majestad y esplendor: con corona, brazaletes y collar, secundada por Eros y rodeada de simbolos $y$ atribuciones, como en el fresco conservado en el Museo Nacional de las Termas en Roma, procedente de la Villa Farnesina ${ }^{9}$.

Sin embargo, el testimonio más significativo e importante del culto de Venus romana con caracteres orgiásticos y esotéricos de origen oriental se opera en Venus Ericina, adorada en el monte Erix, al Noroeste de Sicilia, cercano a la ciudad de Segesta, de origen griego.

Segesta tenía como héroe epónimo a Elimes, fundador legendario que pasaba por ser descendiente de los antiguos migrantes troyanos. (TUClDIDES, $H^{a}{ }^{a}$ Guerra Pelopon. VI, 23 ). Por otra parte Erix, héroe epónimo del lugar, era considerado hijo de Afrodita y de rey sículo Butes, que construyó en aquel monte sagrado un templo en honor a su madre. VenusAfrodita Ericina. (DIODoro XXIII, 5; ZONARES VIII, 9).

Venus Ericina se identificaría con una primitiva divinidad alli venerada, que probablemente tendría caracteres de diosa Gran-Madre mediterránea de la fecundidad indicando unos remotos orígenes prehistóricos.

Las vicisitudes históricas de la isla hicieron correr paralelo el proceso religioso en este lugar derivando a un culto impregnado de caracteres orientales, debido sin duda a las influencias aportadas por los colonizadores semitas, fenicios y púnicos, establecidos en la isla ${ }^{10}$.

Cuando los romanos llegaron y dominaron la isla en el año 248 a.C., no sólo respetaron y conservaron el santuario y los cultos de esta divinidad, sino que, según el relato de Polibio (PoLıBıo I, 55, 6), ésta se integró en la religiosidad romana. No en vano los orígenes de su misma fundación se cimentaban en el troyano Eneas y sus compañeros.

Si los colonizadores semitas y griegos habían reconocido en la antigua diosa de la fecundidad siciliana a sus propias diosas (Anat, Astarté, Afrodita), Roma identificó a la misma con Venus, madre de Eneas y del propio

9 Estudiado por ParaberinI, R., Le Terme di Diocleziano. Roma 1932, pág. 223 y analizado por SCHILLING, R., op. cit., pág. 222.

10 Las representaciones monetales relativas al templo de Erix son claramente significativas al respecto: la diosa aparece coronada, rodeada de palomas (signo de fecundidad en el mundo Egeo y Oriente próximo), la espiga de trigo y el símbolo de la esvástica. A mayor abundamiento, el templo de la diosa ericina tenía un altar a cielo abierto, que siempre mantuvo, propio de los rituales orientales. También tenía a su servicio heródulos, practicándose en su santuario la prostitución sagrada, proceso religioso de origen mediterráneo oriental, tal vez semita (EsTRA. BON, VI, 272; Ciceron, in Q. Caecilium, 55. Sobre el santuario: PolıBıo, I, 55, págs. 7-9; PAU. SANIAS, VIII, 24, 6). 
Erix, incluyendo a la diosa (en su prototipo de Pandémos) en el culto nacional de Roma, gracias a su relación con la leyenda troyana.

También por razones políticas en el período de crisis republicano y a las condiciones del protagonismo adquirido por los grandes generales de aquella época: Sila, Pompeyo y César (que demostraron públicamente su devoción a la diosa e incluso su vinculación personal con la misma), Venus fue elevada al rango de divinidad tutelar del pueblo romano, desarrollándose el culto a Venus Genetrix y creando el primer tipo de estatuaria romana que rompia con la desnudez griega.

Con Hadriano, Venus se unía a Roma definitivamente, construyéndose un templo en las cercanías del Foro dedicado a ambas divinidades, extendiéndose su papel protector al género humano. Venus se nos muestra entonces como una poderosa y venerable matrona vestida y majestuosa en su trono ${ }^{11}$.

Sin embargo, la religiosidad romana continuaría dejándose seducir por la atracción y el encanto de Venus -Afrodita Anadionmene y Pandémos. Su iconografía, su simbolismo y significación fueron irresistibles, no sólo para la espiritualidad popular sino para artistas, poetas y escritores que representaron y cantaron a la que se alababa como divinidad "dulce como la miel para los mortales" (Glucumeilikos) (HIMNo HomérICo V, 19 y X, 2).

\section{Venus en Hispania}

El culto de Venus adquiere una cierta importancia en las provincias romanas de Hispania, como parecen indicar los diferentes testimonios arqueológicos hallados referentes a la diosa. La bibliografía sobre Venus en Hispania es escasa y trata temas parciales ${ }^{12}$.

Ante esta documentación arqueológica, podría sugerirse dos tipos de veneración y culto a la misma:

- Una religiosidad de carácter oficial. Son las dedicaciones a Venus Victrix y Venus Genetrix ${ }^{13}$.

"También Afrodita griega en su naturaleza de Curotrofos desempeñaba el papel protector de madre tutelar que se extiende y conforma en Venus Genetrix.

12 Rodriguez CORTÉs, J., “Venus en la Bëtica a través de la epigrafía», Studia Historica, IV$V, n{ }^{\circ} 1,1986-1987$, págs. 137-1440; SAN NiCOLÁs PEDRAZ, P., "La iconografía de Venus en los mosaicos hispanos", Actas del VI Coloquio Internacional del Mosaico Antiguo. Palencia 1990 (en prensa).

13 Valgan como ejemplos la inscripción de Cástulo dedicada a Venus Genetrix (CIL, II, 3270 y de Tarraco (ARCO, A. del, BAH, 60), o las dedicaciones epigráficas procedentes de la provincia 
- Las manifestaciones dedicadas a Venus que nos remiten a un culto más popular y posiblemente más espontáneo.

En las mismas la diosa es representada o aludida como divinidad del amor, el placer o la fecundidad. Incluso, como ya ha señalado A. Vázquez, podría sugerirse la posibilidad que el culto de Venus en Hispania adquiriera ciertas tendencias de carácter mistérico y funerario, como también se manifestaba en el resto del Imperio ${ }^{14}$.

Así Venus es venerada como señora de las fuentes de la vida y como tal parecen indicar los epítetos de Domina y Sancta con los que es mencionada. Igualmente, Venus es representada desnuda, en el baño, en sus caracteres de Anadiomene y Pandémos.

Lamentablemente carecemos, por el momento, de representaciones de Venus halladas en un contexto claro de tipo funerario, sin embargo poseemos dedicaciones a la misma en epitafios y las imágenes de Venus o de su símbolo, la concha marina en sarcófagos funerarios, que sin duda son testirnonios válidos y notablemente significativos de su relación con el mundo funerario. Valga como ejemplo la representación de Venus en el baño, figura principal del relieve del sarcófago de Ceuta estudiado por N. Villaverde ${ }^{15}$.

En general, las dedicaciones y representaciones referentes a Venus en Hispania, reciben influencias de distintas tendencias locales e incluso de cultos indígenas. Estos factores lejos de complicar y alejarnos de su estudio, incitan a conocer, en la medida de lo posible, la condición de la diosa en el marco de la religiosidad hispana.

\section{VENUS DE TALAVERA (fig. 2-5)}

Se trata de una representación de Venus en bronce hallada en Talavera de la Reina, según los datos ofrecidos por el Museo de Santa Cruz de Toledo, en cuyos fondos se encuentra actualmente depositada. Dicha Ve-

Lusitania a Venus Victrix (C/L, II, 470). También las monedas emitidas en época republicana en Córdoba en honor de Julio César, recogidas en GIL FARRES, G., La moneda hispánica en la edad antigua, págs. 72, 170, 278 y 280, recogido en Vázouez HoYs, A., La religión romana en España. Fuentes epigráficas, arqueológicas y numismáticas. Madrid 1982, págs. 510-523.

14 VÁzQUEZ HoYs, A., "Algunos problemas de la epigrafía religiosa hispanorromana", Coloq. Internacional d'Epigrafía. Culte i Societat en Occident. Tarragona 1988 (en prensa); ibidem, La Diana de Segóbriga, Cap. IV. Cuenca 1993 (en prensa).

is Villaverde VeGa, N., "Sarcófago romano de Ceuta", Actas de/ / Congreso Internacional. El estrecho de Gibraltar, t. I, 1988, págs. 877-905, fechado en el último tercio del siglo III d.C. 
nus fue hallada al lado de la iglesia de San Andrés y comprada por el Museo en 1975.

Restaurada en 1986 y 1988 , ofrece unas medidas de $10 \mathrm{~cm} \times 3,5 \mathrm{~cm}$ $\times 2 \mathrm{~cm}$. Es un producto de fundición plena a molde.

Faltan a esta figurilla ambas piernas por debajo de las rodillas y la mano derecha, el resto de esta pieza se encuentra en buen estado (fig. 2).

Es posible que su superficie se hallara alterada en el momento de su restauración. Ello se hace más sensible en los rasgos faciales: Nariz larga y recta, labios rectos y apenas perceptibles, ojos inexpresivos, conseguidos mediante un simple rehundimiento almendrado sobre el que se intenta marcar las cejas (fig. 3).

El cuello es largo, tal vez excesivamente frágil en relación con el resto del cuerpo, pero consigue proporcionar esbeltez a la figura. Un brazalete simple de oro orna el antebrazo derecho a la altura del codo.

El tratamiento escultórico de la figura es muy plano, sobresaliendo la corpulencia de la cadera sobre el resto del cuerpo. Tal vez fuera trabajada para ser contemplada desde un ángulo inferior, desde donde se puede observar mejor todo el movimiento y detalles de esta pequeña Venus (fig. 4). La diosa está de pie, en posición frontal, apoyándose marcadamente en la pierna derecha que parece extendida, manteniendo la otra flexionada. Ello obliga a una forzadisima torsión en las caderas: Mientras que el torso está en posición frontal, la cadera y extremidades inferiores se encuentran en escorzo, tal vez esta postura se deba para mostrar más resaltadamente sus senos pues la diosa ha sido representada en el momento en que ciñe los mismos con un lienzo de tela. Este lienzo rodea la espalda para volver en sus extremos por delante. Manos y brazos se encuentran pegados al cuerpo en ademán de sujetar dichas cintas y atarlas (Fascia).

Este tipo de Venus con «Fascia» que sujeta o cubre los senos no es precisamente una de las representaciones más frecuentes de la diosa, encontrándose muy escasos ejemplos en los repertorios iconográficos ${ }^{16}$.

Entre las Venus halladas en Hispania sólo conocemos un ejemplar paralelo que cuente con una banda o lienzo cubriendo parte de su cuerpo. Nos referimos a una pieza inédita depositada actualmente en el Museo

15 Ver REINACH, S., Répertoire de la Statuaire grecque et romaine, t. VI. París 1930, pág. 152, n. ${ }^{\circ}$ 5: Epinal, E. 4827, pág. $197, n .{ }^{\circ} 5$ (B. Dresde. Phot; $155, n .{ }^{\circ} 4$ : B. Louvre, 443; n. ${ }^{\circ} 5$ : B. Brunswick, 182; pág. 208, n. ${ }^{\circ}$ 6: B. coll. Salting Burl. Exhib. pl. 47; 210, n. 5 : B. Egipto, Coll. Bissing Ath. Mith., 1907, pl. 3. 


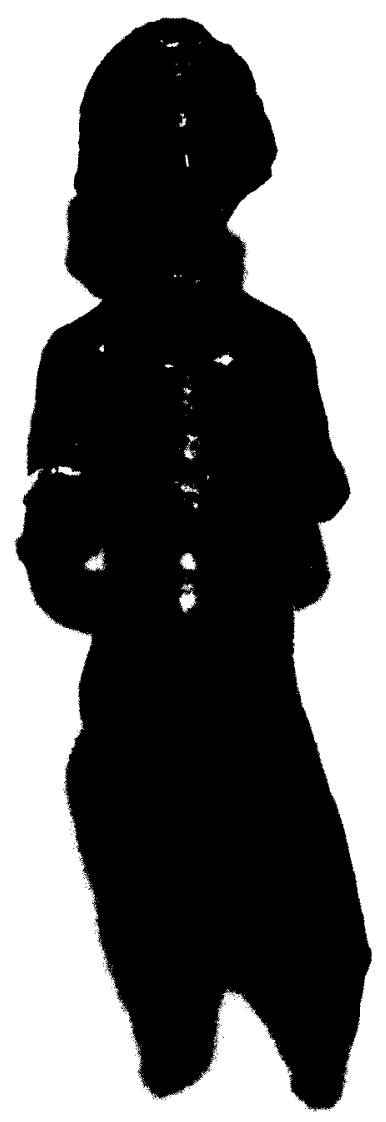

Fig. 2. Venus de Talavera. Vista de frente. Obsérvese la posición de sus manos y brazos, así como el escorzo y movimiento de su cadera (foto: J. J. Palop).

Arqueológico de Barcelona (Sala XXI). Se trata de una estatuilla que representa a la diosa desnuda. La banda de tela cruza diagonalmente el pecho, cubriéndole los senos para volver a emerger a la altura de las caderas, cubriendo el sexo de la diosa. 


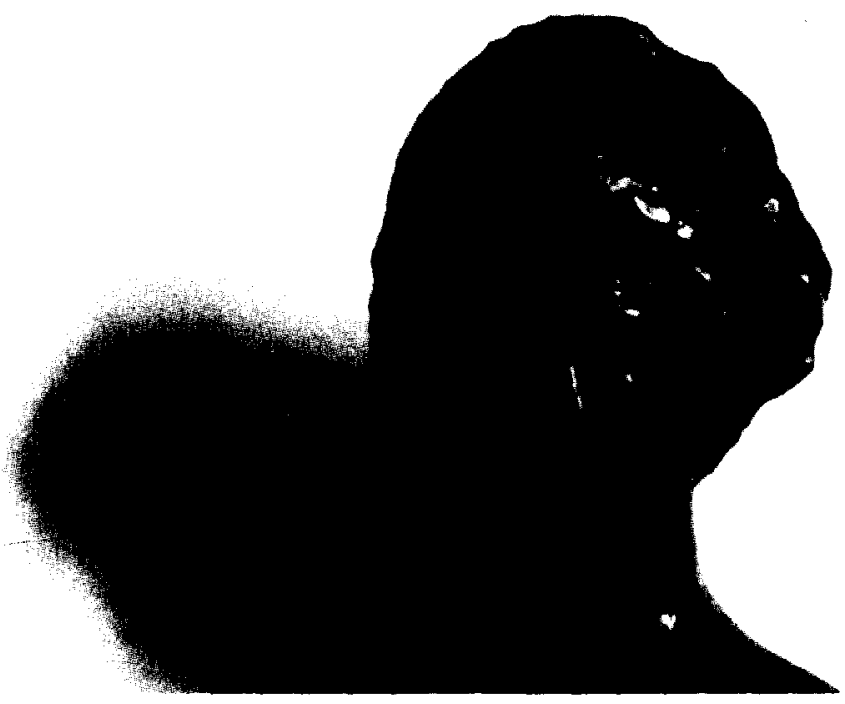

Fig. 3. Venus de Talavera. Detalle del rostro y el peinado (foto: J. Aurrecoechea)

Sin embargo, esta pieza del museo de Barcelona aparece en posición frontal, y tanto su postura como su peinado no ofrece semejanzas sustanciales entre ambas. Además, la posición del lienzo que la cubre y el movimiento de cadera y de las manos, sugieren una manifestación y significado diferente en la Venus que nos ocupa.

Respecto a este tipo de vestimenta que cubre los senos, (Fascia), nos recuerda la que portan las "Jóvenes gimnastas" y la dama de "la escena erótica" representadas en los mosaicos pavimentales de la Villa romana de Piazza Armerina, en Sicilia, fechados entre el 310 y 330 d.C., y considerados de tradición africana ${ }^{17}$.

El interés del artífice se ha centrado además de lograr su movimiento, en el complicado peinado que ostenta la diosa:

El cabello está realizado con gran precisión, dispuesto en tres ondas que rodean la cabeza por encima de la frente. Estas ondas formadas con

17 Sobre la villa romana de Piazza Armerina ver CARANDINI, A., Ricerche sullo stile e la cronologia della Villa di Piazza Armerina. Roma 1964; GentILI, G. V., La villa Erculia di Piazza Armerina; I. Mosaici Figurati. Roma 1959; KäHLER, H., Die Villa des Maxentius bie Piazza Armerina. Berlín 1973. 


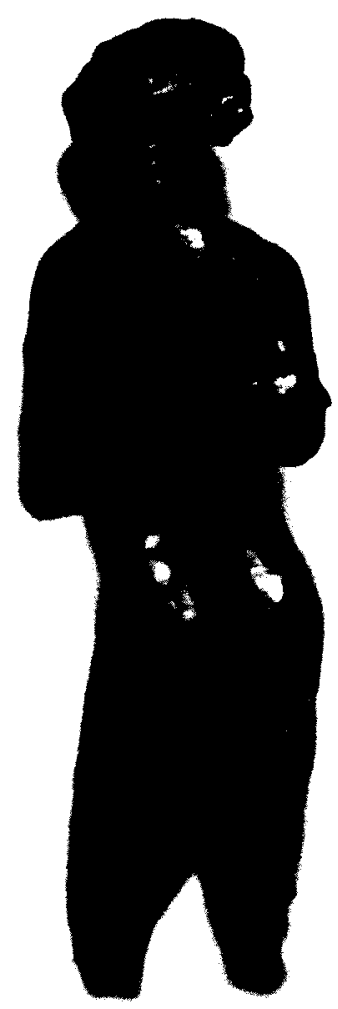

Fig. 4. Venus de Talavera. Vista por detrás. Puede observarse la cinta que cruza su espalda a la altura del pecho, asi como la torsión de su cintura (foto: J. J. Palop).

trenzas se graduan en forma de «nido» en torno a la coronilla, alzándose como una diadema, para acabar en un moño anudado del que sale una coleta suelta que cae sobre la espalda, propio de los peinados de VenusAfrodita (fig. 5). 
Este tipo de peinado tan complicado nos permite datar la figura con cierta precisión, ya que fue usado con similares características por las damas de la época tardo-Flavia y Antoniniana (primer cuarto del siglo II d.C.). Un peinado femenino muy semejante luce Matidia, hija de Marciana, hermana de Trajano, en el retrato de la misma conservado en el Museo Capitolino: (Catal. Museo Capitolino, Cat. 195-PI. 50) ${ }^{18}$.

Sin poder afirmar que esta pequeña Venus de bronce presente unos caracteres claros del tipo Pandémos (diosa del amor, el placer y la fecundidad ya citado), al menos nos sugiere una cierta analogía e incluso podría tratarse de una versión del mismo: La diosa es representada desnuda, ornamentada y en una posición en la que muestra ostensiblemente sus senos.

Estas representaciones de la divinidad desnuda, sujetando o mostrando sus senos son relativamente frecuentes desde épocas muy remotas a lo largo de la cuenca mediterránea, considerándose su origen en las divinidades orientales de la fertilidad, tal vez originarias de Siria y Chipre, que los colonizadores semitas y chipriotas propagaron a lo largo de toda la cuenca mediterránea, llegando a identificarse con Afrodita y Venus del panteón clásico (fig. 1).

En Hispania, sin duda, fue introducido su culto por fenicios y púnicos, perviviendo y adaptándose a la religiosidad romana.

Autores interesados en la religiosidad hispana como A. Vázquez han defendido la pervivencia de los cultos orientales establecidos en la península en su "sustrato prerromano" que sobrevivirian en la civilización romana incluso llegarian a identificarse con sus divinidades ${ }^{19}$.

Por otra parte, Roma aceptaba de forma abierta y oficial la interpretación de la diosa de la fecundidad oriental, con sus atributos y hasta con sus ritos en su función de Venus Pandémos. (Recordemos la importancia del santuario de Venus Ericina). No sería pues difícil de aceptar la im-

18 También es analizado en Wegner, Max, Das Römische Herrschebild. Berlín 1956; Poul. SEN, V., Les portraits romains. Copenhague 1973-1974, págs. 48 y ss., n. ${ }^{\circ} 14, \mathrm{~L}$. 26-27; MANSuelli, G. A., Catal. Galleria degli Uffizi, II, 1961; Fittschen-Zanker, Capit. Mus., III, 1983, n. ${ }^{\circ}$ 67 .

19 VÁzQUez HoYs, A. M. ${ }^{a}$, "Algunas consideraciones sobre cultos locales en la Hispania romana", Memorias de Historia Antigua. Oviedo 1981, págs. 41-50; ibidem, "La tradición religiosa del mundo mediterráneo y la percepción de los cultos romanos", Actas del / Congreso Internacional El Estrecho de Gibraltar, t. I. Ceuta-Madrid 1988, págs. 845-853; BLÁzQUEZ MARTiNEZ, J. M. a Imagen y mito. Madrid 1977, págs. 221 y ss. También sobre este tema GonzÁLEZ WAGNER, C., Fenicios y cartagineses en la Península Ibérica. Madrid 1883; Olmo Lete, G. del y Aubet, M. E. (dir), Los fenicios en la Península lbérica. Sabadell 1986. 


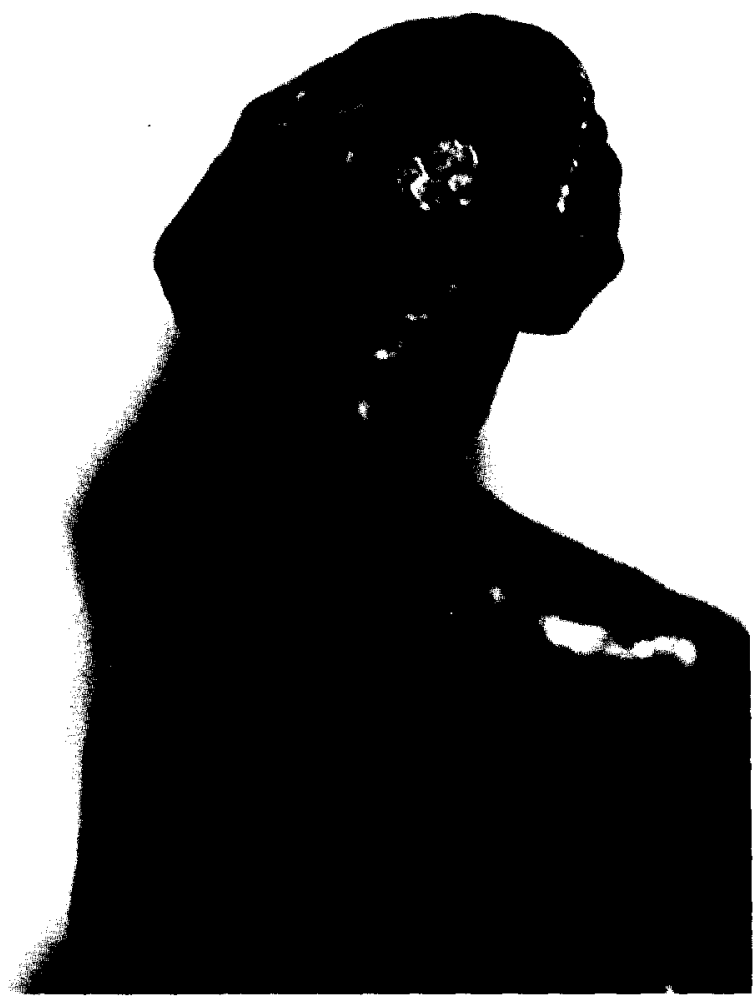

Fig. 5. Venus de Talavera. Detalle de su peinado elevado en torno a la nuca y recogido en moño y trenza, cayendo el cabello por la espalda (foto: J. Aurrecoechea).

portancia y pervivencia del culto a Venus en Hispania como deidad de la fecundidad y la vida como ya antes indicamos.

\section{VENUS DE OCAÑA}

Venus de bronce de $8,7 \mathrm{~cm}$ de altura. Presenta un estado de conservación excelente, faltándole únicamente la pierna derecha por debajo de la rodilla. Se trata, también, de un producto de fundición plena a molde. Como la de Talavera, mantiene la pierna izquierda flexionada, apoyándose 


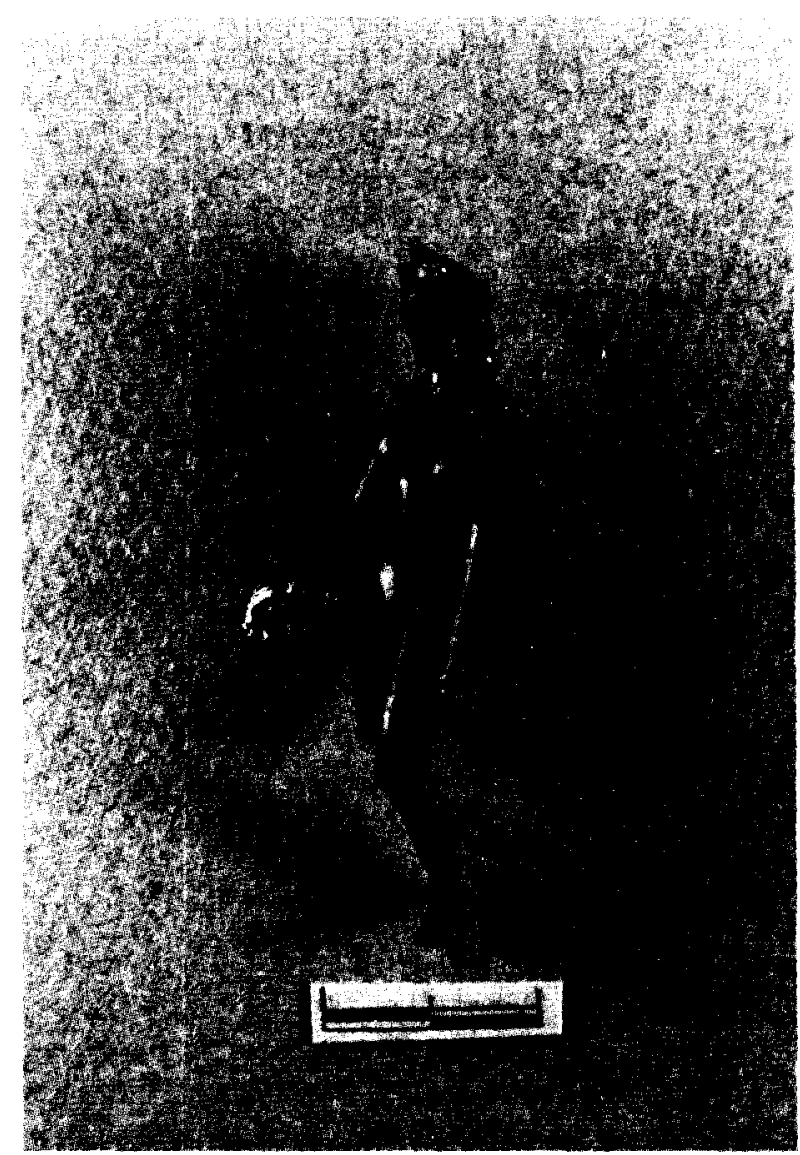

Fig. 6. Venus de Ocaña. Vista frontal de la diosa. Muestra la forma y movimiento de su cuerpo (foto: Alberto G. Leicher).

en la derecha, que tiene extendida, aunque el juego de la cadera se resuelve de forma mucho más sutil y armoniosa. El torso, levemente girado, como corresponde a la actitud que adoptan las piernas, parece adelantarse debido a la posición del brazo derecho, que muestra en su mano una máscara de plata. Ésta representa un rostro infantil, de cara redondeada, mofletes pronunciados y faccion es naturalistas, peinado con un mechón central del que parte el pelo que cae formando ondas sobre las orejas. El brazo derecho de la diosa se flexiona, levantándose por encima del pecho, para sujetarse una de las trenzas. El rostro se encuentra bien conseguido, manifestando una expresión de dignidad muy acorde con el carácter divino de la figura. La nariz recta, los ojos expre- 
sivos, que cuentan con indicación de la pupila, y los labios delicadamente trazados, sorprenden por la calidad de acabado, que en estas estatuillas menores no suelen ser tan cuidado. El peinado, en el que se diferencian claramente los mechones, está compuesto por dos trenzas que flanquean el cuello y un pequeño moño que recoge el pelo de la frente, para luego liberarlo en una frondosa coleta que surca la espalda. Una diadema de cinco perlas o puntas completa el tocado (fig. 7).

La venus encontrada en Ocaña responde al tipo de Afroditas anadiomenas, heterogéneo grupo que recoge a este personaje "saliendo del baño", tal y como nos la muestra el mito hesiódico, cuyo exponente más célebre es la Venus Medicis. Un exponente representativo del modelo inicial lo encontramos en la estatuilla de bronce de la antigua colección Comarmond, en la actualidad en el Museo de Rouen, donde la diosa se plasmó con el himation enrollado, cubriéndole las piernas, mientras que en un gesto púdico dirige la mano izquierda hacia su sexo, cubriéndolo o sujetando la tela que lo cubre, y con la mano diestra se escurre un mechón de pelo (ESPERANDIEU y RoLLAND 1959, 34, n. ${ }^{\circ} 38$ ) .

Sobre esta base se desarrolló una amplia iconografía, que en las obras menores en bronce se convierte en una auténtica profusión de tipos y subtipos, algunos bastante fieles al original y otros meras interpretaciones del mismo. Este fenómeno ha propiciado la acuñación del término «réplica de réplica", adjetivo acertado que define a las producciones provinciales en bronce, basadas en protipos helenísticos (MARINESCU 1981, 74).

La figura toledana que tratamos reúne en si varias de estas interpretaciones, por lo que antes de pasar al estudio corporativo de nuestra pieza con sus congéneres hispanos, analizaremos algunas de las variantes principales del grupo de las Venus anadiomenas en bronce, ya que en ellas encontramos la fuente de inspiración del modelo que comentamos.

Con las del tipo de la Venus de Cnido de Praxíteles, comparte la posición flexionada de la pierna izquierda, así como la posición adelantada de la mano derecha y la desnudez del cuerpo. De las realizadas en bronce siguiendo este esquema formal, destacaremos por su calidad artística, un ejemplar de París (BONNET et alii 1989, 98-99, n. ${ }^{\circ} 31$ ). Otras, de arte mucho más provincial, comparten diversas semejanzas con la Venus hispana, aparte de las características reseñadas, así: la encontrada en Vaison y depositada en el British Museum, análoga en cuanto a la distribución del cabello y la forma de la diadema (RoLLAND 1965, 59, n. ${ }^{\circ} 75$ ), la hallada en Tienen, en el Museo Real de Arte e Historia de Bruselas (FAIDER-FEYTMANS 1979, 83, fig. 48, n. ${ }^{\circ} 77$ ), o la del Museo Denon-Chalon-Sur-Saone (BOUCHER 1983, 92-93, n. ${ }^{\circ} 67$ ), estas dos últimas con una diadema de cinco puntas casi idénticas a la plasmada en la Venus toledana. Si nos 
centramos en el estilo y ejecución de la figura, encontramos dos paralelos muy semejantes al nuestro en una estatuilla de Bavai (FAIDER-FEYTMANS $1957,58-59$, n. ${ }^{\circ} 68$ ), y en otra de París (BONNET et alii 1989). Todas ellas muestran una cierta estilización del cuerpo, que se alarga acentuando la delgadez del personaje, unos senos pequeños, planos y casi varoniles, un vientre y unas nalgas sin apenas volumen curvo, manos alargadas con indicación de los dedos bastante convencional, caras expresivas, centrando el interés en uno ojos en los que se indica la pupila y, por último, la misma minuciosidad en la representación del peinado, que por añadidura muestra una distribución muy parecida en los tres ejemplares. Tanto la Venus de Ocaña, como la de París y Bavai, parecen haber salido de talleres provinciales coetáneos.

Otra variante del grupo de Venus anadiomenas, con la que el ejemplar de Ocaña manifiesta evidentes analogías, también atribuido a Praxíteles, representa a nuestro personaje que acaba de salir del agua. La diosa se escurre o arregla el cabello, siguiendo la iconografía de una pintura de Apeles, aunque a veces realiza este acto con las dos manos y en otras sólo con una, pues con la mano libre sujeta un espejo en el que se contempla. El prototipo para la figura que se escurre los cabellos con las dos manos, parece ser de un contemporáneo de Lisipo. Este modelo gozó de amplia popularidad en el círculo alejandrino. Ambos exponentes de este esquema están representados en sendas estatuillas de la colección Dutuit (PETIT 1980, n. ${ }^{\text {os }} 28$ y 29). Alguna de las figuras que portan espejo, extienden hasta tal punto el brazo que lo sostiene, como un ejemplar de Unterach (FLEISCHER 1967, 71, fig. 44, $n .{ }^{\circ} 75$ ), que lo adelantan en forma muy semejante a la Venus hispana, aunque nunca lo bajan hasta llegar a mostrar la palma de la mano al espectador. Un tipo derivado del que tratamos, son algunas estatuillas que mientras se escurren el pelo con la mano izquierda, extienden la mano derecha para mostrar un fruto, generalmente una manzana. Entre éstas, la Venus de Damerey (BoucHeR $1983,94-95, n .{ }^{\circ} 68$ ), es especialmente importante por los paralelismos que presenta respecto a la postura, con el bronce de Ocaña y por su semejanza estilística con otro de los ejemplares de Venus hispanas, la de Bornos, con la que comparte no sólo el esquema iconográfico sino también el peinado.

Una característica que diferencia a las dos variantes de Venus anadiomenas vistas hasta el momento, y que no creemos anecdótico pues tiene su lógica, es la presencia casi constante de diadema en la categoría de las Venus derivadas de la Cnida, mientras que las representadas escurriéndose o aderezándose el cabello nunca la portan. La ausencia de diadema en el último grupo, vendría explicada por el hecho de tratarse de figuras captadas en un momento de la toilette anterior. 


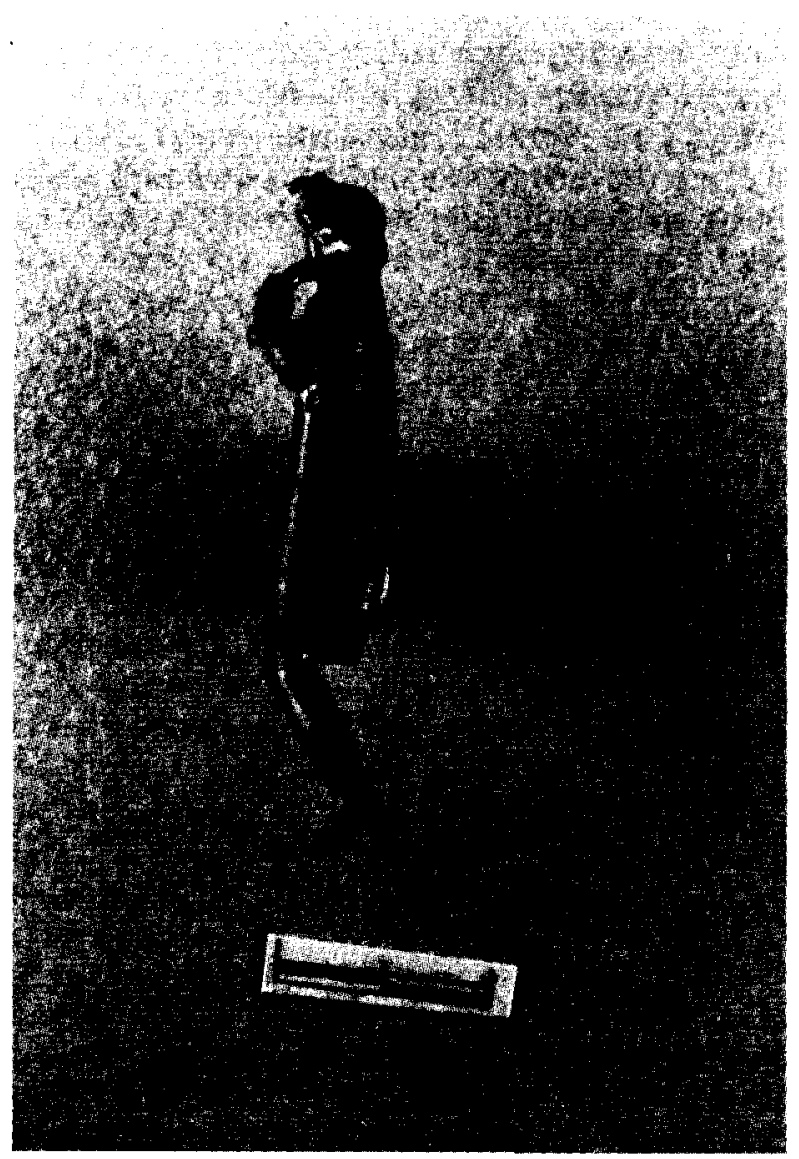

Fig. 7. Venus de Ocaña. Vista de perfil. Muestra su peinado y la mano que recoge el pelo (foto: Alberto G. Leicher).

Una última variante de Venus anadiomenas, sin duda la más importante respecto a la pieza que estudiamos, es un modelo híbrido entre los dos anteriores, ya que nos muestra a la diosa con la mano derecha extendida y la izquierda sujetándose una de sus dos coletas. Este tipo no se halla muy extendido geográficamente, concentrándose los hallazgos en la zona de Dacia (Marinescu 1981, 71-76, fig. 2, n. ${ }^{\text {s }} 3-4$ y fig. $3, n .^{\text {os } 1-4) . ~ T o d a s ~}$ las encontradas en esta provincia romana presentan unas características físicas muy similares, por lo que se consideran producto de un taller local. Cuerpos excesivamente alargados, senos pequeños y vientres planos, dotan a estas estatuillas de un aire juvenil y singular. Si dejamos aparte estas peculiaridades anatómicas, la postura del cuerpo, la mano adelan- 
tada que se extiende para mostrar algo y el gesto de agarrarse la trenza con la mano izquierda, son idénticos al ejemplar toledano que tratamos. El peinado también es análogo, pues se estructura en dos trenzas que caen por los hombros, mientras que todas ellas poseen diadema. Este último elemento suele ser, en las piezas dácicas, en forma decreciente, aunque existen exponentes de diademas con cinco puntas, como la Venus de Potaissa (MARinescu 1981, 74, fig. 3, 2). La cronología no está totalmente fijada, aunque se conoce una estatuilla de Gherla datada en un contexto arqueológico del siglo III d.C. (MARINESCU 1981, 72). Sin embargo, estos pequeños objetos debian tener, como elementos religiosos y de adorno, una vida muy dilatada. Valga como ejemplo la venus hispana de Regina, que si iconográficamente se fecha en la primera mitad del siglo II d.C., apareció en las excavaciones del teatro asociada a un nivel del siglo Iv-v d.C.

El paralelismo de la Venus de Ocaña con sus hermanas de Dacia, cobra una mayor relevancia si tenemos en cuenta, que los ejemplares similares de Venus son realmente escasos en el resto del Imperio. Sólo algunas piezas galas y austríacos, que conozcamos, se aproximan también al esquema que acabamos de describir, así la Venus de Enns (FLEISCHER 1967, 71-72, fig. $45, \mathrm{n} .{ }^{\circ} 76$ ). Tanto las piezas dácicas, como las galas y germanas, muestran un gran esquematismo en las formas, unido a la exagerada estilización del cuerpo. Sin embargo, la Venus hispana, a pesar de cierta estilización, es mucho más naturalista que el resto de los paralelos citados. Nos encontramos, por tanto, ante una reinterpretación hispana, posiblemente adscrita a un taller local, de un modelo con escasa circulación paralela en otras provincias. Su conexión con el peculiar grupo de las Venus de Dacia, producto del sincretismo entre una divinidad local y la Afrodita Clásica (MARINESCU 1981, 74), es un fenómeno que por el momento se nos escapa.

En Hispania el paralelo más exacto, en cuanto a la actitud y pose de la figura, es el ejemplar encontrado en Bornos (Cádiz) (GARCía y BELLIDO $1949,143, n .{ }^{\circ} 148$ ). Al igual que nuestra figura, sostiene en su mano izquierda una de las trenzas, mientras que extiende la derecha con la palma de la mano abierta. El peinado es diferente, pues carece de moño y coleta trasera, no presentando diadema. El tratamiento de las formas también difiere notablemente, estando más en la línea de las representaciones en escultura mayor (curvas marcadas y proporcionadas, relación armónica entre las partes y detalles de corte anatómico), que en la de los bronces menores. No encontramos en su mano extendida, que parece efectuaron además de ofrenda o libación, resto alguno de objeto. Por otra parte, la Venus hallada en Pollentia también cuenta con una mano izquierda extendida, en idéntico ademán que la de Ocaña, mientras que con la otra 
cubre púdicamente su sexo. La forma en que se peina esta figura se asemejan, también, a la toledana. (Fig. 8).

El resto de las semejanzas formas que encontramos entre la Venus de Ocaña y sus homólogas hispanas, únicamente están referidos a aspectos parciales del peinado o el tocador. El peinado "a rollo", con el pelo recogido por detrás en su moño y dos coletas que caen por los hombros, lo encontramos en los ejemplares de Pollentia (PREVOSTI y RAFEL 1983, $59-60, n^{\circ}$ 20) y Libia (GARcía y BELLIDo 1949, 143). Moño y coleta que cae por la espalda posee la pieza sevillana (VV.AA. 1990, 249, n. $\left.{ }^{\circ} 160\right)$. Sendas diademas portan la pieza emeritense (VV.AA. 1990, 247, n. ${ }^{\circ} 159$ ), una inédita del Museo Arqueológico de Barcelona (expuesta en la sala $\mathrm{XXI}$ ) y todas las que acabamos de reseñar. Aunque debemos destacar que ninguna de las diademas constatadas en las otras Venus hispanas, responden a la tipología de la de Ocaña, con cinco perlas o puntas.

Pero un paralelo idéntico, por lo que respecta al peinado, lo encontramos en la Venus de Regina (Nogales 1984, 39-40). La datación de esta estatuilla, en la primera mitad del siglo II d.C., y más concretamente en torno al reinado de Adriano, sería una fecha que convendría, también, al ejemplar toledano, así como, probablemente, a las Venus de Pollentia, Libia y, quizá, a la de Bornos y Sevilla. La pieza hallada en las Baleares es datada por Prevosti y Rafel en época tardía, basándose en su «arte poco cuidado" (Prevosti y RAFEAL 1993, 60), aunque a nuestro juicio, esa peculiaridad la manifiestan casi todas las obras broncíneas realizadas en talleres provinciales durante el siglo II-III d.C.

Esta concentración de pequeños bronces alrededor de una misma temporalidad, dadas una serie de características formales semejantes, que basamos en la analogía del peinado y la presencia de la diadema, hacen pensar en un cierto auge del modelo, posiblemente vinculado a una popularidad del culto a esta divinidad.

Hemos dejado conscientemente en último lugar, el aspecto más singular de nuestra pieza. Éste consiste en la máscara de plata que sostiene en una de sus manos, elemento que no hemos constatado en ninguna de las múltiples representaciones de Venus broncíneas que han sido halladas por todo el Imperio. Esto nos ha hecho pensar en el gusto personal del cliente que compró la estatuilla o del artesano que la ejecutó, que individualizó y revalorizó este producto de taller menor con un trabajo de orfebre.

En efecto, la pequeña máscara argéntea es una obra cuidada, casi miniaturista, realizada con una precisión y acabados propios de una joya. Contrasta con la figura que la sostiene, de un arte mucho más provincial 


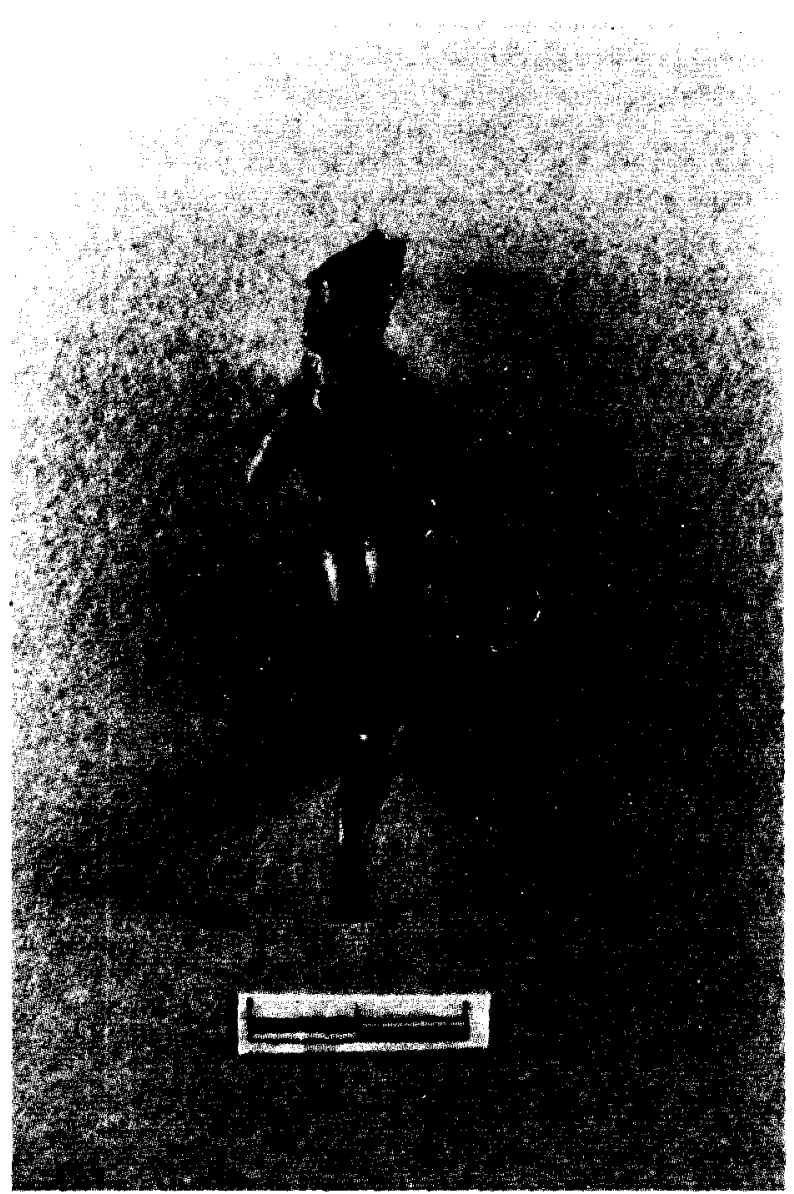

Fig. 8. Venus de Ocaña. Vista por detrás. Se observa con claridad su peinado recogido en un moño para dejar suelto su pelo sobre hombres y espalda; una parte del mismo es sujetado por su mano izquierda. La mano derecha está notablemente desproporcionada en relación con el tamaño de la figura (foto: Alberto $G$. Leicher).

aunque nada descuidado. Por ello nos hemos planteado la posibilidad de que nos encontremos ante un añadido posterior, quizá debido a la pérdida del objeto original que sustentaba el personaje femenino o al mero capricho del posesor.

Puede que la mano en cuestión estuvo planteada desde un principio, para sostener algo en su palma abierta quizá por eso la mano no está proporcionada con el resto del cuerpo, siendo mayor de lo, que le correspondería y no se marcaron sus dedos. La mano izquierda, por el 
contrario, es proporcionada y cuenta con los dedos individualizados. Respecto a la identificación del personaje que se plasmó en dicha máscara es difícil de identificar.

Cabría la posibilidad de que se tratara de una cabeza de Gorgona semejante a la que se encuentra representada en un clípeo que sostienen amorcillos en el relieve que ornamenta el templo de Venus Genetrix de Roma, datado en la época de Trajano ${ }^{20}$.

Sin embargo, aunque esta cabecita representada en el clípeo es muy semejante, carece del nudo mágico tan característico de la Gorgona. Por ello, tampoco parece aventurado conjeturar que nos encontramos ante la representación de Eros, el celoso servidor de Afrodita, a la que ayudaba a embellecerse y acompañaba en sus salidas. El cabello organizado en torno a un flequillo central, a modo de "tupé» levantado nos indica claramente esta atribución iconográfica (STUVERAS, R. 1969).

En las estatuillas de bronce, esta divinidad menor suele representarse emparejado con Venus, casi siempre jugueteando a los pies de la diosa, aunque en otras ocasiones aparece mostrándole un espejo, cabalgando sobre un delfín, o siendo un mero espectador en escenas más complejas. Sin embargo, como ya hemos observado, no hemos constatado ningún caso, a excepción del de Ocaña, donde Eros, si ciertamente se tratara de este personaje, se manifieste en forme de máscara acompañando a nuestra divinidad.

\section{CONCLUSIONES}

Lejos de aislar el estudio de estas dos piezas de bronce, consideramos que ambas se relacionan en un contexto cultural y religioso. Significativamente representan dos concepciones de la divinidad femenina de la fertilidad y de la vida.

Encontramos la necesidad de realizar un estudio más amplio y exhaustivo sobre las representaciones y manifestaciones alusivas a Venus en Hispania que nos permitirían conocer mejor el culto y el concepto de la misma. ¿Es venerada como deidad propiamente romana o se identifi-

20 Ver Hesberg, H. von, «Amoretten, Fries Tempel der Genetrix", ANRW, II, 17, 2, 1987, págs. 1075-1076. También Gross, P., Aure a templa, op. cit., págs. 155 y ss.; Floriani Souarciapino, M., "Panelli decorativi del tempio di Venere Genitrice", Atti Academia Naz. Lincei, Ser. 9, 2, 1948 (1950), págs. 61 y ss.; Stuveras, R., Le Putto dans l'art romain, Coll. Latomus, 99. Bruselas 1969. 
Caría ésta con otra similar indígena, oriental o semita? Confiamos que estas breves aportaciones ayuden al análisis de esta interesante cuestión y esperamos que próximos estudios dedicados a la iconografía de Venus en Hispania nos dirijan a perspectivas más concretas y reveladoras.

Queremos agradecer a don Rafael García Serrano, director del Museo de Santa Cruz y a doña Susana Cortés, conservadora del mismo, su amabilidad e interés al poner a nuestra disposición los fondos cobijados en su institución. Así mismo expresar nuestra gratitud para con don Francisco Fernández de la Cigoña, quien nos permitió el acceso a su colección particular. Nuestro agradecimiento se hace extensivo a la Dra. Ana M. ${ }^{a}$ Vázquez y a los profesores M. Blech y Stephan F. Schöder, del Instituto Arqueológico Alemán, por su valiosa ayuda en el estudio de las piezas.

\section{BIBLIOGRAFIA}

Acuña Castroviejo, F. (1972): “Sobre tres Minervas encontradas en Galicia», Compostellanum 17.

- (1975): “Divinidades romanas en bronce del convento bracarense», Bracara Augusta 29.

Arribas, A. Tarradell, M. y Woods, D. (1973): “Pollentia I. Excavaciones en Sa Portella, Alcudia (Mallorca)", Excavaciones Arqueológicas en España 75.

BALIL, A. (1961): "Materiales para un copus de esculturas romanas del Conventus Tarraconensis", Archivo Español de Arqueología 34.

Bonnet, J. et alii (1989): Les bronzes antiques de Paris, Museo Carnavalet. París.

BOUCHER, S. (1983): Les bronzes figurés antiques. Musée Deno Chalon-Sur-Saone. Chalon-SurSaone.

Esperandieu, E. y Rolland, H. (1959): Bronzes antiques de la Seine-Maritime IIII, Suplemento a Gallia. Paris.

Fider-Feytmans, G. (1957): Recueil des bronzes de Bavai VIII Suplemento a Gallia. París.

- (1979): Les bronzes romains de Belgique. Mainz.

FLEISCHER, R. (1967): Rie Römischen Bronzen aus Osterreich. Römisch-Germanischen Zentral Museum zu Mainz.

Garcia y Bellido, A. (1949): Esculturas romanas de España y Portugal. Madrid.

MARINESCU, L. (1981): "Considerátions concernant l'iconographie de Vénus en Dacie", Mythologie greco-romaine. Mythologies périphériques. Etudes d'iconographie, Coloques internationaux du CNRS 593.

Nogales, T. (1984): «Bronces de Regina", Museos 3.

PETIT, J. (1980): Bronzes antiques de la collection Dutuit. Grecs, Helléniques, romains et de l'antiquité tardive. Palais des Beaux Artes de la ville de Paris, Musee du Petit Palais. París.

Prevosti, M. y Rafel, N. (1983): «Introducción al estudio de las esculturas romanas de Pollentia", Symposium de Arqueologia. Pollentia y la romanización de las Baleares (Alcudia 1977). Mallorca.

RolLAND, H. (1965): Bronzes antiques de Haute Provence XVIII. Suplemento a Gallia. París. VV.AA. (1990): Los bronces romanos en España. Madrid. 